\title{
Petrographic Characterization of Hydrothermal Gold Deposits in Adi Gozomo Area, Northwestern Tigray, Ethiopia
}

\author{
Zelealem Haftu, N.Rao Cheepurupalli
}

\begin{abstract}
Gold mineralization in Adi Gozomo area in northwestern Ethiopia was studied through petrographic analysis from both surface and core rock samples. Mineralization is associated with Neoproterozoic basement rocks comprised of metavolcanic, metasedimentary rocks and intrusives. Four phases of deformation and development of NE-SW foliation and shear zones were some of the common geological structures. The hydrothermal gold deposit $s$ cramped to shear zones, $2^{\text {nd }}$ generation quartz veins, $4^{\text {th }}$ phase of deformation, silisifed and carbonatized alteration zone. Based on decreasing order of abundance the ore assemblage of the area includes pyrite, chalcopyrite, sphalerite, pyrrhotite, arsenopyrite and gold. The petrographic data indicates that the deposit is hydrothermal vein related type and an island arc tectonic setting. The mineralization is comparable with other known orogenic sulfide deposit types of the country in particular and Arabian-Nubian Shield in general.
\end{abstract}

Keywords- Mineralization, Petrography, Hydrothermal, Adi Gozomo, Tigray

\section{INTRODUCTION}

Ethiopia is one of the countries in North East Africa gifted with various types of metallic and non-metallic mineral resources and due to the initiatives taken by the government, mineral exploration activities have been increased for the last two decades that resulted in locating them [1]. However, many of them are still not exploited due to the fact that they are in the exploration and reserve estimation stages. Gold and tantalum are the exceptions, which are being mined in the country. An orogenic gold deposit at Legadembi is being mined by MIDROC Company in southern Ethiopia and auriferous gossan developed on Volcanogenic Massive Sulfide deposit by Ezana Mining Company at Meli in northern Ethiopia (about 10km SW from the study area). Pegmatite hosted tantalum deposit is being mined by Ethiopian Mineral Development Company at Kenticha in southern Ethiopia. But due to their unprofitable way of mining, they are adding minimum towards the

Revised Manuscript Received on December 30, 2019.

* Correspondence Author

Zelealem Haftu*, Department of Geology, School of Mines, Aksum University, Shire, Tigray, Ethiopia. Email: zelealemhaftu@yahoo.com

N.Rao Cheepurupalli, Department of Mineral Processing Engineering, School of Mines, Aksum University, Shire, Tigray, Ethiopia. Email: nraocheepurupalli@gmail.com

(C) The Authors. Published by Blue Eyes Intelligence Engineering and Sciences Publication (BEIESP). This is an open access article under the CC BY-NC-ND license (http://creativecommons.org/licenses/by-nc-nd/4.0/) country's economy [2] eventhough, there are more reports of gold mineralization in the country. These developments have provided enough opportunities to review totally different aspects of those mineralization notably by the educational sectors and others. Many research works have been conducted on Southern Ethiopia and Northern Ethiopia [2,3]. Some Research works are 1) National Mining Company has designated the structurally controlled gold mineralization in Workamba; 2) both Beijing Donia Resources Company and Ezana Mining Development Company (EMD) have reported the presence of volcanogenic massive sulfide (VMS) type $\mathrm{Cu}-\mathrm{Zn}-\mathrm{Au}-\mathrm{Ag}$ deposits in North-western Tigray and eluvial-diluvial gold in western Tigray; 3) Sheba mineral exploration plc reported presence of quartz vein related gold mineralization in Hawizen; 4) EMD has reported gold mineralization at May Hibey and VMS deposit at Meli in NW Tigray. Meli gold-bearing gossan were studied by [4-6].

According to some researchers, the geology of Ethiopia comprises Arabian Nubian Shield (exposed in Northern Ethiopia) and Mozambic belt (exposed in southern Ethiopia) [7]. Searching minerals in Tigray region are started since 1970`s. For example, [8] mapped the region systematically and sub-divided the basement into four formations. The detail study of Northern Ethiopia geology, tectonic setting and geochemical characteristics is presented by [9] $n$ their study on the Axum sheet. He identified and summarized six N-NE striking tectonostratigraphic blocks such as; the Shiraro, Adi Hageray, Adi Nebrid, Chila, Adwa and Mai Kenetal Blocks. Adi Gozomo and Adi Nigisti areas are located within the Nakfa tectono-stratigraphic sequence of Eritrean basement and related to Adi Nebrid Block. The rock units in Adi Nebrid Block are; mafic to intermediate metavolcanics, pyroclastic rocks and immature volcaniclastic sediments, which intruded by dykes, intrusive, veins and granite [9]. Metamorphism, intrusions, deposition and uplifting plays for the reconstructing the geological history of the area [4] and structurally the area is folded, sheared, faulted and predominated by mafic/ultramafic intrusives [9]. In Adi Gozomo area its surrounding, geological map of mineral deposit, recorded alteration pattern and potential target areas and recommends detail mineral exploration [10]. Followed this report and artisanal gold mining in the area, Harvest mining plc reported vein related gold deposit, through trenching and diamond drilling during 2013-15. Although, the above reports recommend presence of gold and base metal mineralization in several areas, however elaborated studies on completely different aspects of those deposits are at foot. 
The present work aims to study the ore petrography, alterations patterns, ore mineral assemblage and paragenesis of gold mineralization from the Adi Gozomo area.

\section{METHODOLOGY}

The activities conducted were; detailed fieldwork, sampling (collection and analyses of samples), mapping (geological), analyses and interpret the results. Harvest Company has made 35 boreholes and among them six boreholes were described, sampled and logged. 20 surface and 16 borehole rock samples were selected from metavolcanic, metasediments, granite and quartz veins for thin section preparation (to study the character of the host rock) and polished section preparation (to study the character of the ore minerals). The preparation was conducted at Mekelle University and the analyses and interpretation at geology department, Aksum University, Ethiopia.

\section{RESULTS AND DISCUSSION}

\section{A. Geology and structure}

The geology of the area forms part of northern Ethiopia which consists of metavolcanics, metasediments, intrusive, quartz veins of different generations, and dykes which are ranked from oldest to the youngest Figure 1. Most of the lithologies follow the regional N-S to NE-SW trend with sub-vertical westward dips, but some lithologies are affected by tectonics and deformation, resulted different orientations. Mostly, the rocks are fine to medium grained and show well developed foliation. The details of lithologies are provided here under. The metavolcanic rocks are fine grained, felsic-mafic in composition, massive, at places jointed, foliated/sheared, follow regional trend and varies in strike from $\mathrm{N} 5^{\circ}$ to $\mathrm{N} 35^{\circ}$ azimuth, with $25-80^{\circ}$ dipping west. The metasedimentary rocks are characterized by fine grained matrix, well developed (foliation, shearing, mineral lineation, crenulations, boundinage) as well as primary compositional banding of minerals and some rock fragments. The metasedimentary rocks are categorized into chlorite-sericite schist, quartz-sericite schist, sericite schist and chert.

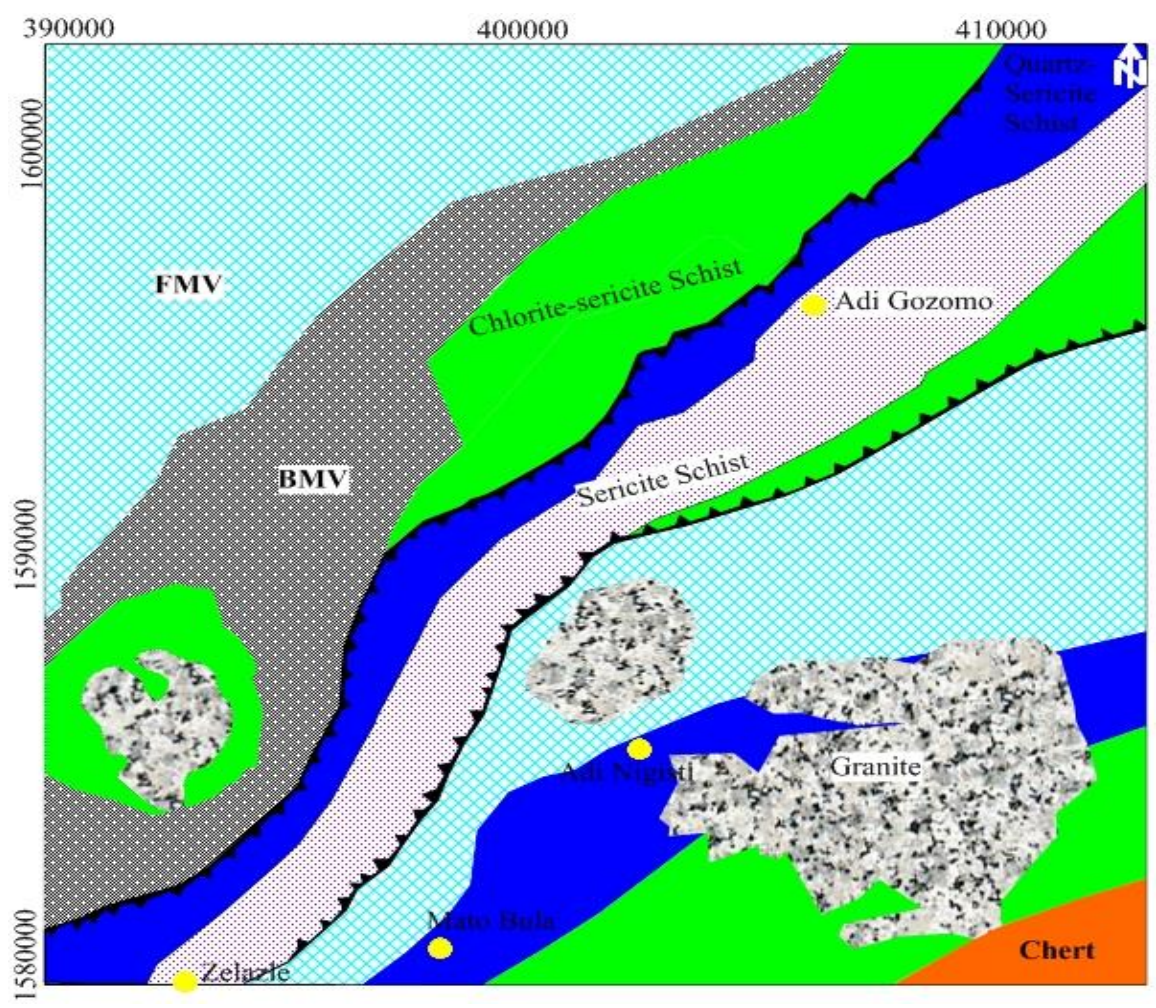

Fig.1. Geological map of the study area (NB: BMV and FMV= Basic Metavolcanic and Felsic Metavolcanic rock units).

Chlorite-sericite schist is the dominant unit among the metasedimentary rocks, follows regional trend N-S with minor deviation about $5-20^{\circ} \mathrm{NE}$, and is intruded by veins, and dykes. It is composed of sericite, quartz, chlorite with coarse grained feldspars and it is in contact with quartz-sericite schist, FMV, BMV and sericite schist. The characteristics of quartz-sericite schist is almost equivalent with chlorite-sericite schist. Other unmappable metasedimentary rock types are sericite-quartz-chlorite schist, chlorite-quartz schist, and chert. Sericite schist shows well developed foliation, shearing and schistocity which trending N-S (with deviation of $5-15^{0} \mathrm{NE}$ ) and dipping $35-75^{\circ}$ west. This rock type shows well developed foliation and crenulations cleavage under petrological microscope which producing $S_{1}$ and $S_{2}$ rock fabric respectively. Chert forms through direct precipitation from silica rich fluids, because chert has the general physical properties of quartz. It occurs in the form of bedded jasp $10 \quad 500-1,000$ and massive jasper above the mineralized meters in turn by sericite schist. Granites broadly follow the regional N-S trend and located along the contact between metasediment and metavolcanic rocks as well as within both the metavolcanic and metasedimentary rocks. They vary in composition from plagioclase-rich to K-feldspar-rich. Mafic intrusive are observed only in the boreholes where as felsic intrusive, intruding mostly metasediments are conspicuous in the area. Fractures, folds and faults and accordingly resulted foliations, schistocity, shear zones, veins and dykes are the common geological structures in the area. 
Foliation shows NE-SW orientation whereas shear zones and inferred faults show NW-SE orientation. Four phases of deformation are observed through S-C fabric, foliation, folds, mylonitized zones, crenulations and mineral lineation. First phase of deformation $\left(\mathrm{D}_{1}\right)$ represent the NE-SW trending folds $\left(\mathrm{F}_{1}\right)$ and penetrative metamorphic foliation $\left(\mathrm{S}_{1}\right)$ that ranges in inclination from sub-horizontal to sub-vertical/vertical. It is prominent in metasediments and less common in metavolcanic rocks (NNE-SSW foliations, dipping to $25-70^{0}$ due west). The $\mathrm{D}_{2}$ is related to the large scale upright sub-horizontal northerly or southerly plunging $\left(F_{2}\right)$ folds, N-S and NE-SW trending shear zones. The third phase of deformation $\left(D_{3}\right)$ is represented by brittle-ductile shear zones which are strongly foliated and fragmented. Fourth phase of deformation $\left(D_{4}\right)$ is a brittle deformation, produced NNE-SSW and WNW-ESE trending strike-slip and thrust faults and lineaments.

\section{B.Petrography}

The petrographical analysis of the present study area is done in two ways, which is country rock petrography and ore petrography.

\section{Rock Petrography}

The rock types associated with the mineralization are metavolcanic, metasedimentry and granites. The detailed petrographic description and Photomicrographs of metavolcanic, metasedimentary rocks and granite are present in Table 1, Figure 2 and Figure 3.

Table-1: Rock petrographic description of the three rock units in the study area.

\begin{tabular}{|c|c|c|}
\hline Metavolcanic rocks & Metasedimentary rocks & Granite \\
\hline $\begin{array}{l}\text {-It shows fine to medium grained } \\
\text { minerals and epidotization, } \\
\text { chloritisation, } \\
\text { carbonatization and serrugenization, } \\
\text { alteration patterns. } \\
\text {-They are composed of plagioclase, } \\
\text { quartz, muscovite, chlorite, and epidote } \\
\text { and are ntruded by quartz veins and } \\
\text { vein lets. } \\
\text {-These rocks have a gradational contact } \\
\text { with the adjacent sericite schist and } \\
\text { Felsic volcanic (Figure } 2 \text { ). }\end{array}$ & $\begin{array}{l}\text {-It shows fine to coarse grained } \\
\text { minerals and cericitization, } \\
\text { chloritization, } \\
\text { alteration patterns. } \\
\text {-They are composed of chlorite, } \\
\text { sericite, quartz, biotite, K-feldspar and } \\
\text { opaque. } \\
\text {-The xenoblastic K-feldspar shows a } \\
\text { poikiloblastic textures (sense of } \\
\text { elongation and aligned parallel to the } \\
\text { poorly developed foliation). } \\
\text {-Different generation dykes, quartz } \\
\text { veins/veinlets, foliation and } \\
\text { crenulations cleavage were observed. }\end{array}$ & $\begin{array}{l}\text {-Located in contact with metasediment } \\
\text { and metavolcanic rocks and follow } \\
\text { N-S regional trend. } \\
\text {-It shows randomly distributed } \\
\text { minerals and dominated by } \\
\text { sericitization, chloritization and } \\
\text { epidotization. } \\
\text {-They consisted of k-feldspar, chlorite, } \\
\text { biotite, calcite, quartz, epidote and } \\
\text { minor opaque minerals. } \\
\text {-Mafic intrusives are observed only in } \\
\text { the boreholes where as felsic intrusive } \\
\text { are conspicuous in the area. }\end{array}$ \\
\hline
\end{tabular}
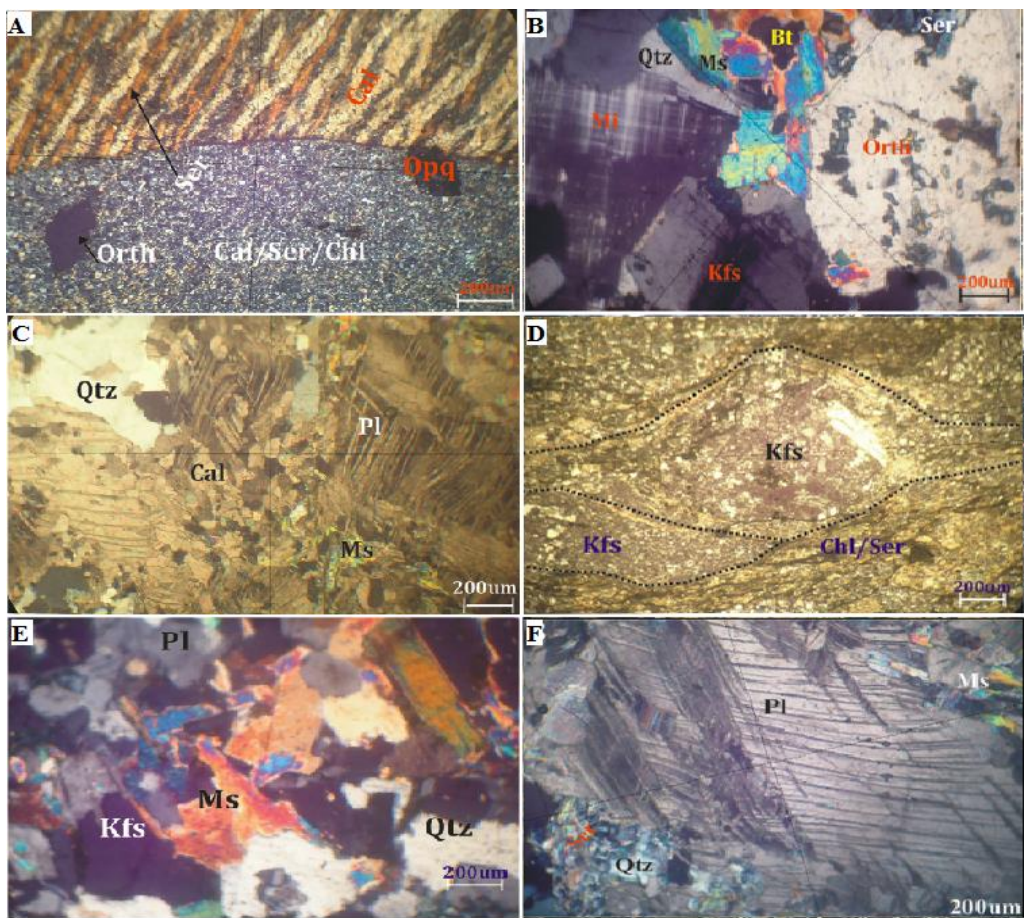

Fig.2. Photomicrographs, A) sericite-chlorite schist under PPL, B) felsic volcanic rock under PPL; C) quartz-sericite schist under PPL; D) feldspar-sericite-chlorite schist under XPL (k-feldspars show sense of shearing due to deformation); E\&F) plagioclase-muscovite-quartz rock under PPL (NB:Kfs-k-feldspar, Pl-plagioclase, Qtz-quartz, Chl-chlorite, Ms-muscovite, Ser-sericite, Cal-calcite, Mi-microcline, Bt-biotite,Orth-orthoclase, Opq-opaque).

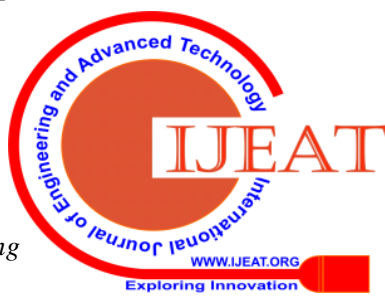




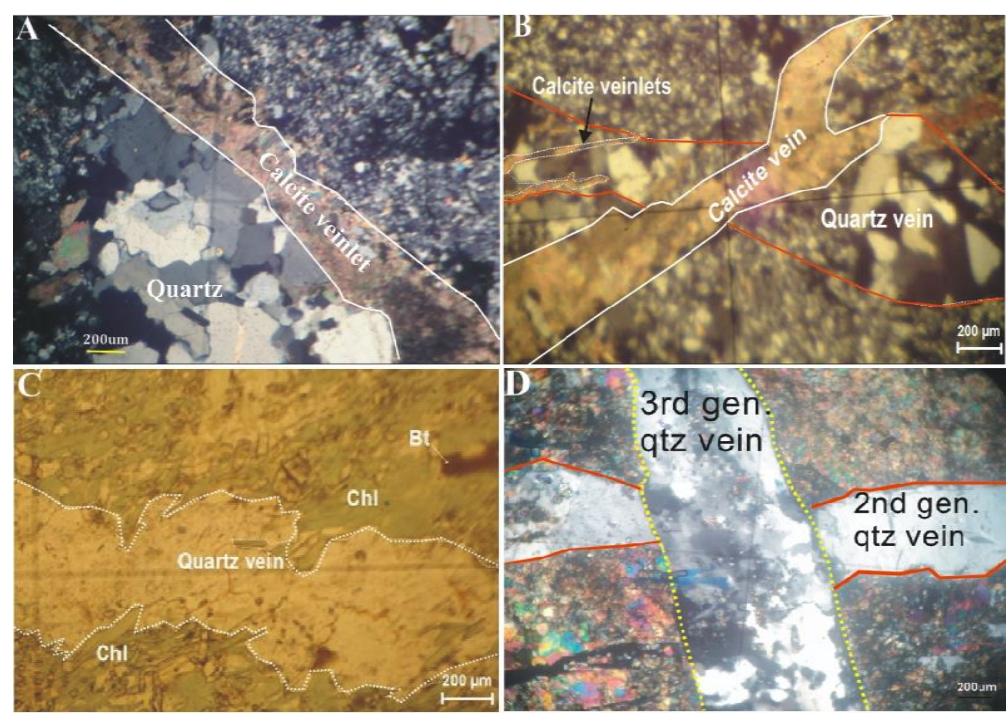

Fig.3. Photomicrographs, A\&B) Quartz-sericite schist cutting by quartz and calcite veins/veinlets under XPL, B) Chlorite-sericite schist cutting by second and third generation quartz veins under XPL (NB: Chl-chlorite and Bt-biotite).

\section{Ore Petrography}

The study of polished sections indicates presence of native gold and sulfides (Figure $4 \mathrm{~A}-\mathrm{F}$ ). The detailed description of ore pertographic studies are elaborated in Table 2. Sulfides include pyrite, pyrrhotite, chalcopyrite, galena and sphalerite. The polished sections composed of fine to medium grained, and euhedral (with cubic outlines) to subhedral yellow pyrite, brown irregular pyrrhotite, grey sphalerite, medium to fine irregular cream galena, medium to fine grained brass yellow chalcopyrite and fine grained gold showing isotropic property with golden yellow color. They are mainly associated with quartz veins and are disseminated. Gangue minerals often occur within the pyrite showing poikilioblastic texture.

Table-2: Ore petrographic description of the area.

\begin{tabular}{|c|c|}
\hline Mineralization type & Auriferous quartz veins and base metal sulfides. \\
\hline $\begin{array}{l}\text { Arrangement based on } \\
\text { dominancy }\end{array}$ & $\begin{array}{l}\text { Pyrite, chalcopyrite, sphalerite, pyrrhotite, arsenopyrite and native gold n decreasing } \\
\text { order of abundance. }\end{array}$ \\
\hline Texture & $\begin{array}{l}\text { Chalcopyrite blebs are interpreted as exsolution (chalcopyrite disease) and fracture } \\
\text { filling. Sphalerite shows nclusions of sphalerite-chalcopyrite ntergrowths. Pyrrhotite is } \\
\text { irregular, medium to fine grained, occur together with chalcopyrite. Arsenopyrite is } \\
\text { medium to coarse grained, euhedral to irregular; occur as dissiminated, inclusion and } \\
\text { vein filling similar to pyrite. The fresh arsenopyrite is similar in size and shape with } \\
\text { pyrite I. } \\
\text { Gold is fine grained, irregular and occurs in native form. Shows five different types of } \\
\text { textures. 1) monomineralic and annealing texture (arsenopyrite and pyrire I), 2) } \\
\text { exsolution texture (sphalerite and chalcopyrite), 3) replacement texture (chalcopyrite } \\
\text { and chalcocite), 4) porphyroblasic texture (arsenopyrite and pyrite I) and 5) disseminated } \\
\text { texture (gold). }\end{array}$ \\
\hline Forms & $\begin{array}{l}\text { Pyrite occurs in two forms 1) Deformed pyrite (pyrite-I) and 2) undeformed pyrite } \\
\text { (pyrite-II). Pyrite-I is medium to coarse grained, irregular shape and highly affected by } \\
\text { gangue and seem formed together with chalcopyrite, pyrrhotite and sphalerite. } \\
\text { Pyrite-II is fresh, medium to coarse grained, euhedral and cut across the earlier ore } \\
\text { minerals including the gangue. }\end{array}$ \\
\hline $\begin{array}{l}\text { Secondary } \\
\text { mineralization }\end{array}$ & $\begin{array}{l}\text { Chalcocite and limonite are present as secondary mineral produced due to supergene } \\
\text { enrichment and weathering. }\end{array}$ \\
\hline $\begin{array}{l}\text { Generation of quartz } \\
\text { vein }\end{array}$ & $\begin{array}{l}\text { Pyrite-I, chalcopyrite, pyrrhotite and sphalerite-represents first generation where as } \\
\text { pyrite-II, arsnopyrite and gold represents second generation hydrothermal quartz veins. }\end{array}$ \\
\hline Inclusions & $\begin{array}{l}\text { Within arsenopyrite inclusions of pyrite, chalcopyrite, pyrrhotite and sphalerite are } \\
\text { common. }\end{array}$ \\
\hline
\end{tabular}

Field observations combined with laboratory results, suggest occurrence of the ore minerals filling the fractures mainly in the shear zones often in close proximity to wall rock alteration and this result is similar with the results of this authors. [4,11].

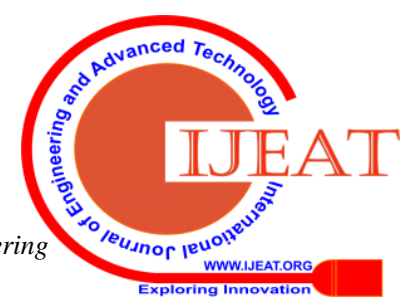




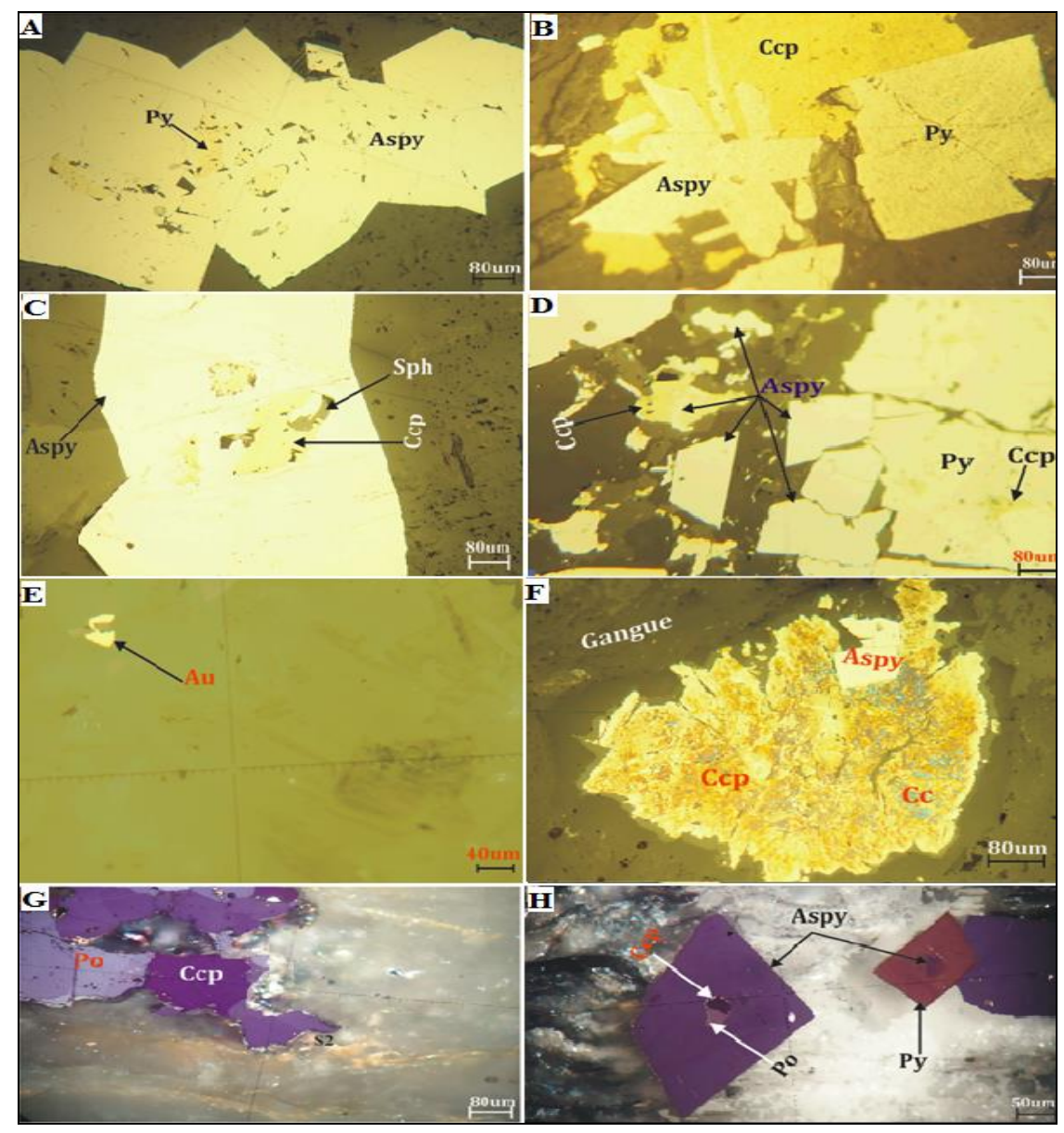

Fig.4. Photomicrographs llustrating: (A) pyrite nclusion within arsenopyrite (PPL); B) aggregate of pyrite, chalcopyrite and arsenopyrite (PPL); C) chalcopyrite \& sphalerite $n$ arsenopyrite (PPL); D) pyrite with chalcopyrite and arsenopyrite (PPL); E) gold (PPL); F) arsenopyrite replace chalcopyrite and chalcopyrite altered to chalcocite (PPL); G\&H) pyrrhotite replace chalcopyrite.

\section{A. Paragenetic Sequence}

With the help of mineral relationships and association, morphology of the mineral, alteration patterns, deformational phases, mode of formation and textural characterization, the sequence of mineral formation were determined. So, the order of emplacement of hydrothermal vein type ore minerals in Adi Gozomo area is pyrite, arsenopyrite, pyrrhotite, sphalerite, chalcopyrite, gold, and followed by chalcocite and limonite (Figure 5). The solid line indicates certainty where as others uncertainty and the roman numbers indicate the different generation hydrothermal mineralization.

\begin{tabular}{|c|c|c|c|c|c|}
\hline \multicolumn{6}{|c|}{ Time $\rightarrow \rightarrow \rightarrow \rightarrow \rightarrow \rightarrow \rightarrow \rightarrow \rightarrow \rightarrow \rightarrow \rightarrow \rightarrow \rightarrow$} \\
\hline \multirow[t]{2}{*}{ Minerals } & \multirow[t]{2}{*}{ Disseminated } & \multicolumn{2}{|c|}{ Hydrothermal Mineralization } & \multirow{2}{*}{ 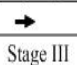 } & \multirow[t]{2}{*}{ Replacement } \\
\hline & & Stage I & Stage II & & \\
\hline Pyrite & $\longrightarrow$ & - & 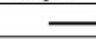 & & \\
\hline Chalcopyrite & & - & & & \\
\hline Pyrrhotite & & $\longrightarrow$ & & & \\
\hline Sphalerite & & 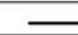 & $--? ?$ & & \\
\hline Arsenopyrite & & - & $\longrightarrow$ & & \\
\hline Gold & & & $---?$ & & \\
\hline Chacocite & & & & & $\longrightarrow$ \\
\hline Limonite & & & & & 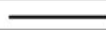 \\
\hline Quartz & & $\longrightarrow$ & $\longrightarrow$ & & \\
\hline Calcite & & & & L & \\
\hline
\end{tabular}

Fig. 5. Shows time relationship between sulfides, gold and alteration $($ Solid line $=$ Certain, $\& . . . ?=$ Uncertain $)$.

\section{C.Mineralization}

Ore minerals associated with narrow, non-persistent and sharp boundary quartz veins are the characteristics of shallow level deposits [12]. The minerals in Adi Gozomo area are ruled by aqueous fluids, quartz veins and weak zones. The orogenic gold deposits from Adi Gozomo area were compared with both other deposits like Workamba \& Lega dembi and the details are given in Table 3.

Ore petrographic data indicates that; 1 ) spreaded pyrite is formed through $\mathrm{D}_{1}$ and vein related pyrite, arsenopyrite, pyrrhotite, chalcopyrite, sphalerite and gold formed by $\mathrm{D}_{2}$. Pyrite I and coarser arsenopyrite are related to $D_{3}$. The secondary minerals chalcocite and limonite later formed. The sources for the mineralization may be felsic to mafic metavolcanic rocks, where as the metasedimentary rocks act as hosts. This vein related mineralization can be correlated with May-Hibey gold mineralization [11], South-west extension of Adi Gozomo area. But, interestingly, arsenopyrite is identified in this study, compared to other gold mineralizations in Tigray where it is absent e.g. Workamba, May Hibey etc), but predominant in Shelewa area [4]. Interims of source rocks, tectonic setting and geological structures the area s comparable with Workamba, May-Hibey, Shelewa areas.

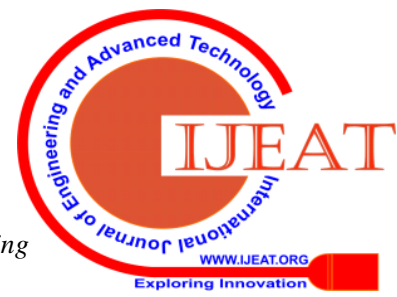


The tectonic setting of the area is Island arc and this tectonic setting and trending of the geological structures is

matched up with that of May-Hibey and Axum [11, 13].

Table-3: Orogenic gold comparisons Adi Gozomo area with both Workamba \& Lega dembi(NB: Ccp = Chalcopyrite, Py = pyrite, gal $=$ galena, $\mathrm{Sph}=$ Sphalerite, $\mathbf{P o}=$ Pyrrhotite, Arsp $=$ Arsenopyrite and Au $=$ gold $)$.

\begin{tabular}{|c|c|c|c|c|}
\hline Characteristics & Orogenic deposits & $\begin{array}{l}\text { Workamba gold } \\
\text { mineralization }\end{array}$ & $\begin{array}{c}\text { Adi Gozomo gold } \\
\text { mineralization }\end{array}$ & $\begin{array}{c}\text { Lega dembi gold } \\
\text { mineralization }\end{array}$ \\
\hline Age & $\begin{array}{c}\text { Middle-Late Archean, } \\
\text { paleoproterozoic, } \\
\text { Phanerozoic } \\
\end{array}$ & Late Neoproterozoic & Neoproterozoic & Late Proterozoic \\
\hline Tectonic setting & Convergent margins & $\begin{array}{c}\text { Accreted intraoceanic } \\
\text { arcs } \\
\end{array}$ & Island arc & $\begin{array}{l}\text { Intracontinental rifting } \\
\text { and strike-slip shearing }\end{array}$ \\
\hline $\begin{array}{l}\text { Structural } \\
\text { setting }\end{array}$ & $\begin{array}{l}\text { Structural highs during } \\
\text { compressional and } \\
\text { transtensional stresses } \\
\end{array}$ & $\begin{array}{l}\text { Shear zones, folds } \\
\text { and faults }\end{array}$ & $\begin{array}{l}\text { Shear zones, fracture } \\
\text { and faults }\end{array}$ & $\begin{array}{l}\text { Shear zones, fractures, } \\
\text { folds and faults }\end{array}$ \\
\hline Host rocks & $\begin{array}{c}\text { Mainly mafic volcanic, or } \\
\text { intrusive rocks, } \\
\text { greywacke- } \\
\text { slate sequences }\end{array}$ & $\begin{array}{l}\text { Volcano-sedimentary } \\
\text { sequence }\end{array}$ & $\begin{array}{l}\text { Mainly sericite schist } \\
\text { and quartz veins }\end{array}$ & $\begin{array}{c}\text { Feldsphatic gneisses } \\
\text { and } \\
\text { volcano-sedimentary } \\
\text { sequences }\end{array}$ \\
\hline Metamorphic grade & $\begin{array}{l}\text { Greenschist facies (from } \\
\text { subgreenschist } \\
\text {-greenschist? }\end{array}$ & Greenschist facies & Greenschist facies & $\begin{array}{l}\text { Upper-greenschist to } \\
\text { lower-amphibolite }\end{array}$ \\
\hline Intrusion & Felsic-lamprophyre dykes & Felsic-mafic dykes & Felsic-basic dykes & Felsic-mafic dykes \\
\hline Ore minerals & $\begin{array}{l}\text { Py common then Arsp, } \\
\text { Po, gal, Sph, } \\
\text { and Ccp }\end{array}$ & $\begin{array}{l}\text { Py dominate, } \\
\text { followed by Sph, gal, } \\
\text { Ccp, Po \& Arsp }\end{array}$ & $\begin{array}{c}\text { Py dominate } \\
\text { followed by } \\
\text { Ccp, Sph, Po, Arsp, } \\
\text { and Au. }\end{array}$ & $\begin{array}{l}\text { Ccp, gal, Po and Py are } \\
\text { dominant Arsp, } \\
\text { bournonite, } \\
\text { molybdenite, \& minor } \\
\text { Au. } \\
\end{array}$ \\
\hline $\begin{array}{c}\text { Mode of } \\
\text { Occurrence } \\
\end{array}$ & $\begin{array}{l}\text { Native gold, electrum or } \\
\text { gold bearing tellurides }\end{array}$ & Invisible micron size & Native gold & Microscopic gold \\
\hline Mineralization style & $\begin{array}{c}\text { Large veins, replacement } \\
\text { of Fe-rich rocks }\end{array}$ & $\begin{array}{c}\text { Quartz-calcite-wall } \\
\text { rock } \\
\end{array}$ & $\begin{array}{c}\text { Quartz veins, } \\
\text { veinlets/stringers }\end{array}$ & $\begin{array}{l}\text { Swarms of quartz veins, } \\
\text { veinlets and stockworks }\end{array}$ \\
\hline $\begin{array}{l}\text { Hydrothermal } \\
\text { alteration }\end{array}$ & $\begin{array}{l}\text { Sericitization, } \\
\text { silicification, } \\
\text { carbonatization, } \\
\text { sulfidization }\end{array}$ & $\begin{array}{l}\text { sulfidization, } \\
\text { carbonatization, } \\
\text { sericitization, } \\
\text { silicification } \\
\text { and propyltic }\end{array}$ & $\begin{array}{c}\text { Sericitization,silicificat } \\
\text { ion,carbonatization, } \\
\text { argilic, } \\
\text { propylitic and } \\
\text { sulfidization } \\
\end{array}$ & $\begin{array}{c}\text { Actinolite/tremolite-bio } \\
\text { tite-calcite-sericite and } \\
\text { chlorite- calcite-epidote } \\
\text { assemblage }\end{array}$ \\
\hline
\end{tabular}

\section{D.Genetic suggestion}

The orogenic lode gold deposits are typically formed through deformational- magmatic- volcanic processes [14, 15]. Similarly, the mineralization of the area is judged orogenic type that has similarity with gold mineralization at May-Hibey and Shelewa area [4, 11]. The ore minerals are formed through hydrothermal solutions concentrated to the locally developed shear zones and are structurally controlled. The host rocks and solutions act for formation of the mineralization, where as the geological structures served as path of metal and solutions migration/precipetation, in association with different alteration patterns and quartz \pm calcite veins. The hydrothermal gold deposit is cramped to shear zones, $2^{\text {nd }}$ generation quartz veins, $4^{\text {th }}$ phase of deformation, silisifed and carbonatized alteration zones. By considering this idea, the mineralization automatically linked with dehydration, devolitization and hydrothermal proceses, rather than intrusions which also contribute. As a result, both the ore and gangue minerals fabricated through hydrothermal processes as part of orogenic conditions. The presences of different sulfide minerals indicate the contrubtion of magmatic sources. For example, occurrence of pyrrhotite indicates ultramafic source where as, gold and chalcopyrite mafic source. Absence of galena is an indication non-contribution from felsic sources. The presence of arsenopyrite in the mineral assemblage clearly suggests its contribution from the metasediments and the pyrite-I and II linked the contribution of intrusive granite to the hydrothermal process. Finally, the ore and gangue minerals in the area are associated with both host rock and geological structures, which are correlated with the ore mineralization in Workamba (Northern Ethiopia) and Lega dembi (southern Ethiopia) $[16,17]$.

\section{CONCLUSION}

The geology of the area encompases three rock units arranged from older to younger i) metavolcanics, ii) metasediments mainly of schist variety, and iii) granites. The metasedimentary rocks show well developed foliation, lineation, alteration, shear zone, predominates by quartz vein and undergo mineralization compared to the other rock units. The presence of both ductile and brittle deformation simply the rocks of the area undergone four phases of deformation $\left(D_{1}-D_{4}\right)$. The mineralization is defined by a complex paragenesis of gold in association with $\mathrm{Cu}-\mathrm{Fe}-\mathrm{Zn}-\mathrm{As}$ and related to the intrusion. The ore assemblage includes pyrite, chalcopyrite, sphalerite, pyrrhotite, arsenopyrite and gold in the decreasing order of abundance.

\section{ACKNOWLEDGMENTS}

Authors duly acknowledge Aksum University for providing fund. The support provided by Harvest mining company is highly appreciated for supplying borehole samples and their help in vehicle for the field work. 


\section{REFERENCES}

1. UK. Aspermont, "Ethiopia facts and proud independence". Albert house, 1 singer street London EC2A 4BQ. Mining journal special publication, Ethiopia, 2011, 15p.

2. S. Tadesse, Mineral resources potential of Ethiopia. Addis Ababa University Press, ISBN: 978-99944-52-14-9, Addis Ababa, 2009, 290p.

3. D. J. Deksissa, "Geochemistry, alteration and genesis of gold mineralization in the Okote area, southern Ethiopia". Geochemical journal, 38, 2004, 07-331.

4. H. Zelalem, \& K. Bheemalingeswara, "Petrography of Hydrothermal Gold Mineralization n Shelewa Area, West of Hawzein, Tigray, Northern Ethiopia”. International Journal of Earth sciences and Engineering, 11(2), 2018, 200-207.

5. A. Samuel, K. Bheemalingeswara, \& G. Solomon, "Geology of volcanogenic massive sulfide deposit near Meli, northwestern Tigray, northern Ethiopia. Momona Ethiopian Journal of Science, 7(1), 2015, 85-104.

6. K. Bheemalingeswara, and Atakilt Araya, "Rahwa auriferous gossan, northern Ethiopia: A strong ndicatorfor subsurface massive sulfide mineralization". International Journal of Earth Sciences and Engineering, 5 (3), 2012, 402-408.

7. A. Asrat, P. Barbey, and G. Gleizes, "The Precambrian Geology of Ethiopia: a review”, Africa Geoscience Review, 8, 2001, 271-288.

8. D. Levitte, “The geology of central part of Mekelle sheet (ND37-11) Ethiopian Institute of Geological Survey. Note No. 821-201-12: 66, 1970.

9. T. Tadesse, M.Hoshino, \& Y. Sawada, "Geochemistry of low-grade metavolcanic rocks from the Pan-African of the Axum area-Northern Ethiopia”. Precambrean Research, 99, 1999. 101-124.

10. Howe International LTD, "Satellite image interpretation of the May Hibey block, Tigray, Ethiopia”, Berkhamsted Herts, UK. (Unpubl.). 2011.

11. G, Mickiale, and K. Bheemalingeswara, "Hydrothermal Gold Mineralization and Structural Controls near May Hibey, Northwestern Tigray, Northern Ethiopia”, Momona Ethiopian Journal of Science, 9(2), 2017, 162-181.

12. F. P. Bierlein, D. . Groves, R. J. Goldfarb, and A. B. Christie "Lithospheric footprints of giant orogenic gold systems", 2010, 125 pages.

13. M. Alene, R Ruffini, and R. Sacchi, "Geochemistry and geotectonic setting of Neoproterozoic rocks from northern Ethiopia (Arabian-Nubian Shield)". Gondwana Research, 3, 2000, 333-347.

14. R. J. Goldfarb, D.I.iGroves, and S. Gardoll, Orogenic gold and geologic time: a global synthesis. Ore Geology Reviews, 18, 2001, 1-75.

15. E. L. Klein, K. Harris, A. Giret, C. A. V iMoura, \& S. R. Angelica, "Geology and stable isotope $(\mathrm{O}, \mathrm{H}, \mathrm{C}, \mathrm{S})$ constraints on the genesis of the Cachoeria gold deposit, Gurupi Belt, northern Brazil”, Chemical Geology, 221, 2005, 188-206.

16. S. Gebresilassie, "Nature and characteristics of metasedimentary rock hosted gold and base metal mineralization in the Workamba area, central Tigray, northern Ethiopia”, Ph.D. thesis, at Ludwig-Maximilians University, Munich, Germany, 2009, 134 p.

17. S. Tadesse, "Genesis of the shear zone related gold vein mineralization of the Lega Dembi gold deposit, Adola gold field, Southern Ethiopia', Gondwana Research, 7(2), 2004, 481-488.

\section{AUTHORS PROFILE}

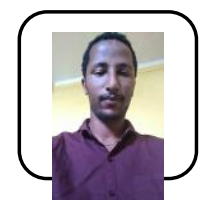

Mr. Zelealem Haftu, is working in department of Geology, in school of Mines, Aksum University, Ethiopia. He completed his MSc in the field of Earth science specialization in Economic Geology from Mekele University, Ethiopia. He actively participated in research and community services in national and international level. He has published more than 5 papers in national and international journals of repute.

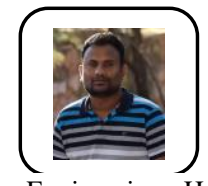

Dr. N. Rao Cheepurupalli, is working as an Assistant professor in the department of Mineral processing Engineering, School of mines at the Axum University, Ethiopia. He has more than 6 years of teaching experience in the field of Mining and Mineral Processing Engineering. He is one of the Member of ESIA report for the establishment of Iron Ore Mining and Steel Making Plant at Indasillase, Tigray, Ethiopia. He has published more than 12 papers in national and International journals of repute. He has presented more than 8 papers at different places in the conferences and seminars. 